\title{
Dr. Milton Lee Wagner, MD (1931-2020)
}

\author{
Thierry A. G. M. Huisman ${ }^{1}$
}

Received: 4 September 2020 / Revised: 4 September 2020 / Accepted: 8 October 2020 / Published online: 21 November 2020

(C) Springer-Verlag GmbH Germany, part of Springer Nature 2020

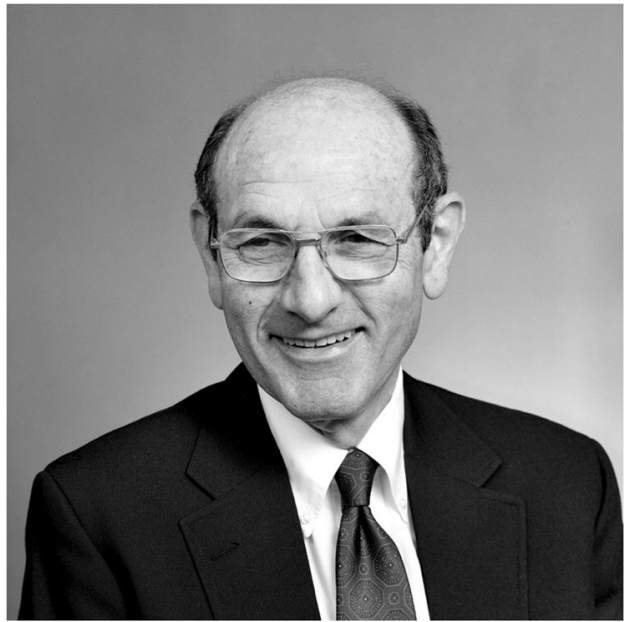

Dr. Milton Lee Wagner, 89, passed away Aug. 26, 2020, surrounded by his family. Milton was one of the three founding members of the pediatric radiology service at Texas Children's Hospital in Houston. Together with his colleagues and dear friends Dr. Edward B. Singleton and Dr. Robert V. Dutton, he was instrumental in helping to establish pediatric radiology as a separate radiologic specialty.

People who worked with Milton remember him as a mensch who was gentle, calm and patient, with a sharp sense of humor. He took excellent care of everyone and was beloved by his young patients. He was a highly regarded clinician and an influential educator for and mentor to numerous aspiring physicians. He enjoyed meeting with executives, colleagues and friends over a cup of coffee to discuss how to approach

Thierry A. G. M. Huisman

huisman@texaschildrens.org

1 Edward B. Singleton Department of Radiology,

Texas Children's Hospital and Baylor College of Medicine, 6701 Fannin St., Suite 470, Houston, TX 77030, USA and solve complex issues. One recent photo showed Milton exactly in this setting, looking straight into the camera, with a smile on his face and a large cup of coffee in front of him.

Milton was born in Port Arthur, TX, on Feb. 24, 1931, to Sam and Mary Sukman Wagner. He attended Thomas Jefferson High School in Port Arthur, graduating in 1948 before heading to the University of Texas. At UT, his areas of study were zoology and biology. He was a member of Sigma Alpha $\mathrm{Mu}$ and the honorary pre-med fraternity Alpha Epsilon Delta.

His commitment to scholastic excellence and personal achievement earned him acceptance into medical school after only 3 years as an undergraduate student. He graduated from the University of Texas Medical Branch (Galveston) in 1955 and was inducted into the honorary medical fraternity Alpha Omega Alpha. Following his graduation, he served as a flight surgeon in the United States Air Force in Goose Bay, Labrador. He completed his internship and residency at Philadelphia General Hospital (1957-1961).

In early 1962, he was introduced to Barbara Sue Alpard and they married on July 1, 1962, at Westwood Country Club in Houston. After their wedding, they returned to Philadelphia for Milton's fellowship in pediatric radiology at St. Christopher's Children's Hospital with Dr. John Kirkpatrick (1962-1963). Upon completing his fellowship, Milton and Barbara returned to Texas, where he joined the staff at Parkland Hospital in Dallas. After a year, they moved to Oklahoma City, where he practiced adult radiology at Baptist Hospital with his uncle Dr. Robert Sukman. Milton and Barbara welcomed their first child, son Bradley, in February 1965.

In late 1966, Milton accepted an offer from Dr. Singleton to come to Houston to help develop the pediatric radiology service at Texas Children's Hospital. Six months later, Milton's daughter Alisha was born in June 1967.

Milton practiced at Texas Children's for 34 years as a highly respected and devoted member of Singleton Associates. In 1983, he served as president of the TCH medical staff. As an academician, he was appointed as a clinical professor of 
radiology at Baylor College of Medicine. His numerous academic contributions included co-authoring two books, Radiologic Atlas of Pulmonary Abnormalities in Children and Radiology of the Alimentary Tract in Infants and Children, with Drs. Singleton and Dutton. Milton was the lead author of a landmark article, "Typhlitis: A Complication of Leukemia in Childhood," one of the first reports on the imaging appearance of typhlitis in children, published in the American Journal of Roentgenology, Radium Therapy, and Nuclear Medicine in 1970.

In addition to many family trips with their children, Milton and Barbara enjoyed traveling internationally as well as attending out-of-town medical conferences, where they made long-lasting friendships. They were season-ticket holders to the Houston Symphony and the Houston Ballet. In later years, they took up ballroom dancing and spent many an evening showing off their new skills. Milton enjoyed fine wine, dining out, art and classical music. He enjoyed reading classic works of fiction and stories of life in Europe and life during World War II.

In 2003, Milton and Barbara were blessed with grandchildren Jake and Rebecca, and in 2005, Madelyn. They relished attending the kids' school plays, athletic competitions and grandparent events. They adored their grandchildren, often referring to them as the "Little Darlings." Taking a page from their digital world, Milton enjoyed texting with them.

His beloved Texas Longhorns highlighted Milton's lifelong enthusiasm for sports and athletic competition. He had football season tickets for more than 50 years, enjoying UT games in Austin and at home with family and friends. Another of his great sports passions was the Boston Red Sox, this one originating from his adoration of Ted Williams. Milton was also a fan of the Dallas Cowboys and enjoyed fond memories of taking his dad, Sam, to games at the Cotton Bowl in the franchise's formative years. Houston's teams, though, were never far from his heart, especially the Rockets, for which he was a longtime season-ticket holder.

His membership in professional organizations included the John Caffey Society, Radiological Society of North America and the Society for Pediatric Radiology. He is remembered for regaling his colleagues with tales of interactions with Dr. Caffey. Milton also was a member of Congregation Emanu El, the Jewish Community Center and the Texas Exes.

Milton was predeceased by his wife, Barbara, in 2012, just 2 weeks shy of their 50th wedding anniversary. He is survived by his son, Bradley; daughter Alisha and her husband, Jonathan Risch; sister Rae and her husband, Paul Engel; grandchildren Jacob, Rebecca and Madelyn; sister-in-law Shirley Schnitzer; niece Julie Schnitzer; nephews Stephen Engel, Gary Schnitzer and Jeff Schnitzer; and numerous cousins. He will also be remembered fondly by his many friends, colleagues and trainees.

Thierry A. G. M. Huisman on behalf of Bradley Wagner, Alisha Wagner, Bruce Parker and Eric Faerber 